\title{
REPRODUCTIVE ECOLOGY OF A NEOTROPICAL CICHLID FISH, Cichla monoculus (Osteichthyes: Cichlidae)
}

\author{
CHELlAPPA, S., ${ }^{1}$ CÂMARA, M. R., ${ }^{1}$ CHELLAPPA, N. T., \\ BEVERIDGE, M. C. M. ${ }^{2}$ and HUNTINGFORD, F. A. ${ }^{3}$ \\ ${ }^{1}$ Post-graduate Programme in Aquatic Bioecology, Department of Oceanography and Limnology, \\ Centre of Bioscience, Universidade Federal do Rio Grande do Norte, Praia de Mãe Luíza, s/n, CEP 59014-100, \\ Natal, RN, Brazil \\ ${ }^{2}$ Freshwater Fisheries Laboratory, Faskally, Pitlochry, Perthshire PH16 5LB, UK \\ ${ }^{3}$ Fish Biology Group, Division of Environmental and Evolutionary Biology, Institute of Biomedical and Life \\ Sciences, Graham Kerr Building, University of Glasgow, Glasgow G12 8QQ, UK \\ Correspondence to: Sathyabama Chellappa, Post-graduate Programme in Aquatic Bioecology, Department of \\ Oceanography and Limnology, Centre of Bioscience, Universidade Federal do Rio Grande do Norte, Praia de Mãe \\ Luíza, s/n, CEP 59014-100, Natal, RN, Brazil, e-mail: chellappa@bol.ufrn.br \\ Received January 14, 2002 - Accepted May 8, 2002 - Distributed February 28, 2003
}

(With 6 figures)

\begin{abstract}
The reproductive ecology of the freshwater fish Cichla monoculus Spix, 1831 (Osteichthyes: Cichlidae) was investigated in the Campo Grande Reservoir, Northeast Brazil. Rainfall, temperature, $\mathrm{pH}$, dissolved oxygen and electrical conductivity of the water were recorded monthly. Fish collected on a monthly basis were measured, weighed, dissected, sexed and the stage of maturation of the gonads were assessed by macro and microscopic means. The semi-arid study region has short spells of rain of 2-3 months duration interspersed with dry seasons. A positive correlation was observed between rainfall and air and water temperatures and conductivity of the water. The study population had an extended spawning season, with peak reproductive activity coinciding with low water temperatures. Males were longer and heavier than females on average and were larger at onset of sexual maturity. The size frequency distributions of the oocytes indicate that $C$. monoculus is a multiple spawner with an estimated batch fecundity of 3100 . Condition factor showed an inverse relationship in relation to gonad size during maturation in both sexes and spent fish were in poor condition. In mature males, lipid stores in the post-occipital cephalic protuberance, a secondary sexual characteristic developed during the reproductive phase, which depleted in spent individuals. The success of this fish is attributed to its reproductive capacity and to the phenotypic plasticity that allows it to adapt to the harsh ecological conditions that prevail in the semi-arid region of Northeast Brazil.
\end{abstract}

Key words: Cichla monoculus, ecology, cichlids, reproduction.

\section{RESUMO}

Ecologia reprodutiva de um ciclídeo neotropical, Cichla monoculus (Osteichthyes: Cichlidae)

A ecologia reprodutiva do peixe dulcícola tucunaré comum, Cichla monoculus Spix, 1831 (Osteichthyes: Cichlidae), foi investigada na barragem Campo Grande, Nordeste brasileiro. Foram coletados mensalmente os dados da pluviosidade, temperatura, $\mathrm{pH}$, oxigênio dissolvido e condutividade elétrica da água. Os peixes coletados foram medidos, pesados e dissecados, os sexos foram identificados e os estádios de maturação gonadal foram avaliados macro e microscopicamente. A região semi-árida estudada apresentou curto período de chuvas, com cerca de 2-3 meses de duração, intercalados por períodos de estiagem. Foi observada correlação positiva entre pluviosidade, temperaturas do ar e da água e condutividade elétrica da água. A população estudada apresentou amplo período de desova, com picos reprodutivos coincidindo com as temperaturas mais baixas. Os machos alcançaram maior 
comprimento e peso que as fêmeas. Os diâmetros dos ovócitos indicaram que o C. monoculus apresenta desova múltipla, com fecundidade por cada lote estimada em 3100 ovócitos. O fator de condição apresentou relação inversa com o tamanho das gônadas, durante a maturação, em ambos os sexos. Os machos maduros apresentaram protuberância cefálica pós-occipital, de caráter sexual secundário extragenital, com reserva lipídica, que desapareceu nos machos esvaziados. O sucesso reprodutivo desse peixe é atribuído a sua capacidade reprodutiva e plasticidade fenotípica, que permitem sua adaptação às condições adversas da região semi-árida do Nordeste brasileiro.

Palavras-chave: Cichla monoculus, ecologia, ciclídeos, reprodução.

\section{INTRODUCTION}

Amazon fishes have developed a marked degree of physiological plasticity that allows them to adapt to a highly variable natural environment (Val \& Almeida-Val, 1995; Val et al., 1996). In recent years a number of Amazonian fishes of commercial importance, including tucunare, Cichla monoculus, curimatã pacu, Prochilodus marcggravii, apaiari, Astronotus ocellatus, tambaqui, Colossoma macropomum, pirapitinga, Piaractus brachypomum, pirarucu, Arapaima gigas, and pescada do Piauí, Plagioscion squamosissimus, have been introduced into the reservoirs of the semi-arid north-eastern Brazil (Abreu \& Silva, 1987). Prior to this, the fish fauna of this region consisted only of piranha, Serrasalmus nattereri, pirambeba, Serrasalmus rhombeus, and muçum, Synbranchus marmoratus, which were not commercially important, besides the exotic Tilapia rendalli and Oreochromis niloticus (Câmara, 1996).

Of the introduced species, only three have become sufficiently adapted to the semi-arid conditions to effectively contribute to fish hatchery production. The percentage composition of the species that contribute to the local fisheries is as follows: Plagioscion squamosissimus (40\%), Oreochromis niloticus (18\%) and Cichla monoculus $(16 \%)$, besides the freshwater prawn, Macrobrachium amazonicum (16\%), Astronotus ocellatus (4\%) and other fish species (6\%) (Abreu \& Silva, 1987). Cichlids thus contribute $38-40 \%$ of the reservoir fishery production of northeastern Brazil and an understanding of their ecology is therefore of some economic importance. The present study focuses on the reproductive ecology of an introduced population of one of the cichlid, Cichla monoculus.

Although taxonomic citations in relation to C. monoculus in this part of Brazil have referred to it as $C$. ocellaris Bloch \& Schneider or as $C$. ocellaris Steindachner, 1801 (e.g., Fontenele, 1950; Almeida et al., 1993), the species studied in the present study was confirmed as Cichla monoculus Spix, 1831 on the basis of morphometric and meristic measurements (E. Ferreira, National Institute of Amazonian Research - INPA, Manaus, Brazil, pers. comm.). Val \& Honczaryk (1995) confirm the presence of $C$. monoculus and $C$. temensis in the Amazon system. C. monoculus is carnivorous in the adult phase and can attain a length of $700 \mathrm{~mm}$ and a weight of $4 \mathrm{~kg}$ within 3 years in Northeast Brazil (Câmara \& Chellappa, 1996). The fish is shiny yellowish green in appearance, with three vertical black patches on the body below the dorsal fin, while on the base of the caudal fin there is a circular black patch surrounded by brilliant yellow colour. The adults exhibit sexual dimorphism. The onset of reproductive activity is characteristically marked in the male by the appearance of a bright yellowishorange post-occipital cephalic hump, which gradually becomes darker in colour and disappears after the breeding season.

At present little is known about the reproductive ecology of these introduced populations. The present study aims at describing the annual variation in reproductive activity and to relate this to environmental conditions.

\section{MATERIAL AND METHODS}

\section{Study area}

The Campo Grande Reservoir, located in the Municipality of São Paulo do Potengi, in the State of Rio Grande do Norte, is situated between latitudes $05^{\circ} 50^{\prime} 00^{\prime \prime}-05^{\circ} 55^{\prime} 00^{\prime \prime} \mathrm{S}$, and longitudes $35^{\circ} 45^{\prime} 00^{\prime \prime}-35^{\circ} 50^{\prime} 00^{\prime \prime} \mathrm{W}$. The reservoir was constructed in 1984 and has a water storage capacity of $34 \times 10^{6} \mathrm{~m}^{3}$. 


\section{Fish sampling programme}

Samples of about 20 C. monoculus were captured monthly from the reservoir by hook and line. A total of 146 fish were collected during the study period (August 1997 to July 1998). Samples were immediately transferred to ice and transported by insulated cool box to the Icthylogical Laboratory of the Department of Oceanography and Limnology, Federal University of Rio Grande do Norte, Natal, Brazil. Here they were weighed, measured and frozen $\left(-10^{\circ} \mathrm{C}\right)$ until they could be further processed. The sample size was sufficiently large to allow accurate estimations of the various biometric and histological variables without depleting the population.

\section{Environmental parameters}

Rainfall data for the study period were obtained from the Meteorological Station of Natal (EMPARN). Using standard equipment and techniques (Stirling, 1985) hydrological data, including air temperature (thermometer; $\pm 1^{\circ} \mathrm{C}$ ), dissolved oxygen and water temperature (YSI, Model 51B, $\pm 1^{\circ} \mathrm{C}$ ), $\mathrm{pH}$ (Hanna; $\pm 0.01 \mathrm{pH}$ unit) and conductivity (Aquatic Eco-systems, Model Pinpoint; $\pm 0.01 \mu \mathrm{S} \mathrm{cm}^{-1}$ ) of the surface water were recorded between 8:00 $\mathrm{h}$ and 9:00 $\mathrm{h}$, once per month. Measurements were made in an area of open water, approximately $500 \mathrm{~m}$ from the reservoir observation tower. Three measurements of each variable were made each month and average monthly values calculated.

\section{Reproductive status}

Fish were weighed (QUIMIS, Model QI3000 , precision $\pm 1 \mathrm{~g}$ ) and total length determined by measuring board ( $\pm 1 \mathrm{~mm})$. Fish were dissected, sexed and the weights of the liver and gonads recorded (SAUTER, Model D-7470, precision \pm $0.1 \mathrm{mg}$ ). Body condition was estimated by Condition Factor and Hepatosomatic Index, where:

Condition Factor $(\mathrm{CF})=\mathrm{W} / \mathrm{L}^{3} \times 10^{6}($ Le Cren, 1951);

Hepatosomatic Index (HSI) $=100$ (wet wt liver in $\mathrm{g}) /($ total body wet wt in $\mathrm{g}$ - wet wt liver in g) (Wootton et al., 1978).

Mean monthly fish weights were used in the calculations.

Reproductive status was assessed by observation of secondary sexual characteristics and by the gonadosomatic Index (GSI):
GSI $=100$ (wet wt gonads in g)/(total body wet wt in $\mathrm{g}$ - wet wt gonads in $\mathrm{g}$ ).

The location and general appearance of the gonads was noted. Histological examinations of the gonads and the post-occipital cephalic hump of adult males were carried out on sections stained by the hematoxylin-eosin method (Michalany, 1990). Fecundity and oocyte size frequency distribution studies were made following the methods of Vazzoler (1996). Oocyte size measurements were made under binocular microscope (x 20) by eyepiece micrometer $( \pm 1 \mu \mathrm{m})$.

Measurements of the height of the postoccipital cephalic hump in 24 fully mature males were made by micrometer (Norfol; $\pm 50 \mu \mathrm{m}$ ).

\section{Analysis of data}

Data sets were checked for normality and logarithmically transformed when necessary. Standard errors (SE) were calculated to show the precision of the estimated means. Correlations between all the environmental variables were tested using Spearman's non-parametric correlation.

\section{RESULTS}

\section{Environmental variables}

The Fig. 1 summarises the levels of six environmental variables over the study period.

Monthly rainfall in the study area varied from 0 to $143 \mathrm{~mm}$ (Fig. 1a). There was no rain during September-November, monthly rainfall peaking in February and again in July. Air temperature (Fig. 1b) varied from $24.5^{\circ} \mathrm{C}$ to $31^{\circ} \mathrm{C}$, increasing during the dry period from August to December and diminishing during the rainy season from December onwards. Surface water temperature ranged from $26^{\circ} \mathrm{C}$ to $29.2^{\circ} \mathrm{C}$, with a peak in February (Fig. 1c). Dissolved oxygen levels in the water varied from $2.9 \mathrm{mgL}^{-1}$ to 8.0 $\mathrm{mgL}^{-1}$, highest values being recorded in October and May and lowest values during March and June (Fig. 1d). The conductivity of the water was always high, varying from $998 \mu \mathrm{Scm}^{-1}$ to 1359 $\mu \mathrm{Scm}^{-1}$. The minimum value was registered in October and the maximum value in July (Fig. 1e). The $\mathrm{pH}$ values varied from 7.0 to 8.5 (Fig. 1f), the maximum being recorded in August, followed by a slow decline throughout the rest of the experimental period. 

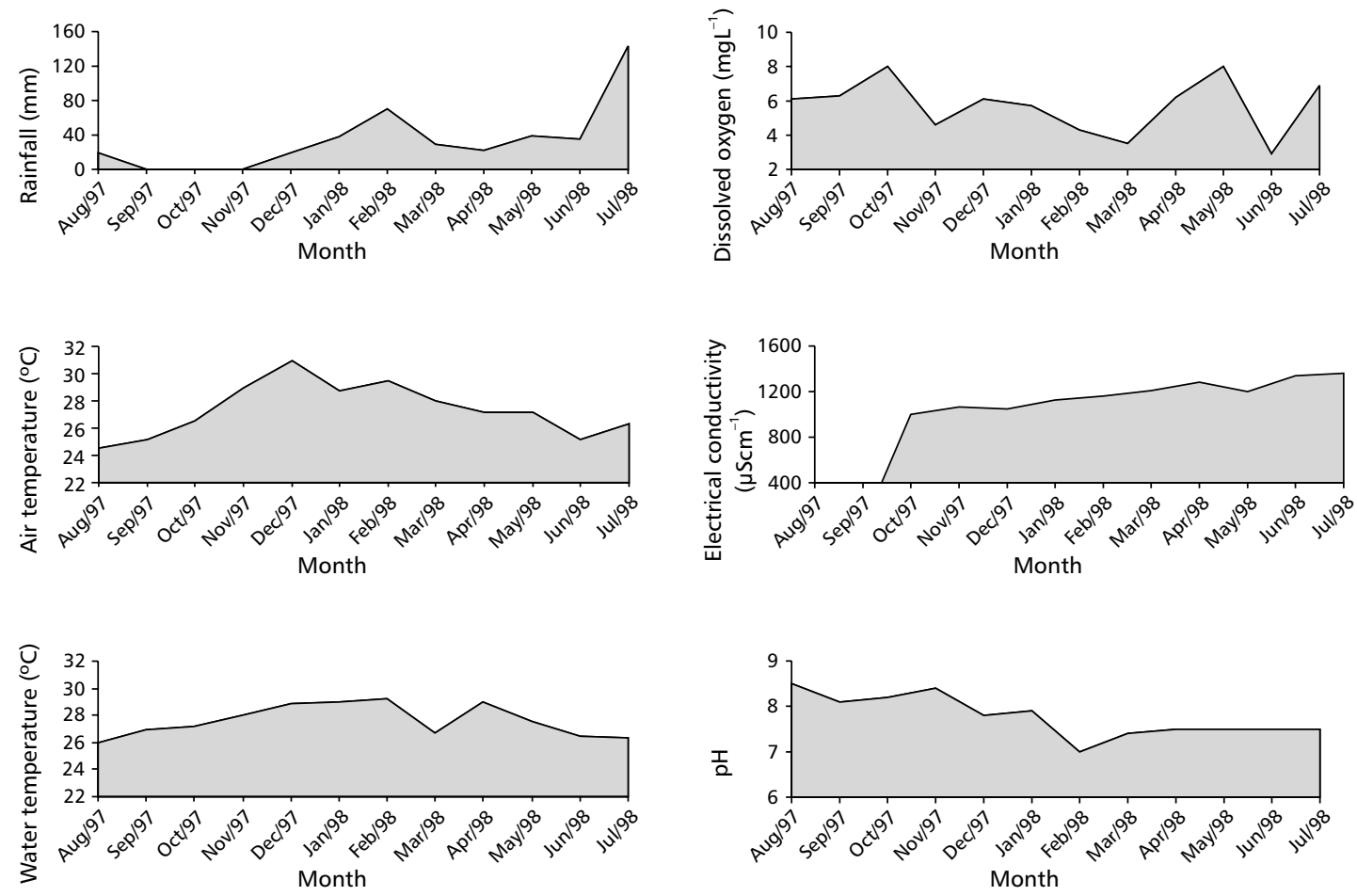

Fig. 1 - Rainfall and physico-chemical data of Campo Grande Reservoir. (a) Rainfall; (b) air temperature; (c) water temperature; (d) dissolved oxygen; (e) electrical conductivity; (f) $\mathrm{pH}$.

There was a positive correlation between rainfall and air temperature $(0.078 ; \mathrm{p}<0.05)$. The temperature variation of the surface waters was similar to that of the air temperature, and Pearson's Correlation confirmed a positive relationship $(0.053 ; p<0.05)$ between rainfall and water temperature, coinciding with the minimum and maximum values of rainfall $(0 \mathrm{~mm}$ in October, 97 and $143 \mathrm{~mm}$ in July, 1998). There was a positive relationship between conductivity and rainfall $(0.673 ; \mathrm{p}<0.05)$. Variations in $\mathrm{pH}$ were negatively correlated with rainfall. The lowest $\mathrm{pH}$ registered in February 1998 ( $\mathrm{pH} 7.0$ ) corresponded to a rainfall of $70 \mathrm{~mm}$.

\section{POPULATION STRUCTURE}

During the study perid, 76 females and 70 males were collected. Cichla monoculus male and female distribution frequency occurrence showed that the sex ratio was approximately $1: 1$ with a slight predominance of females $(52.05 \%)$, however, the difference was not statistically significant at $5 \%$ level. The proportion of males and females was equivalent $\left(\chi^{2}<3.84\right)$. Table 1 shows the variations which occurred on a monthly basis.

The Fig. 2 shows the distribution frequency of lengths and weights of males and females in the total sample. Males were significantly larger (194$338 \mathrm{~mm} \mathrm{SL}$ ) and heavier (96-492 g) than females (178-322 mm; 52-448 g).

\section{REPRODUCTIVE STATUS}

\section{Gonad maturation}

Males were longer and heavier than females when the mean values were considered and were larger at first sexual maturity. $\mathrm{L}_{50}$ Test (Santos, 1978) showed that fifty percent of males $\geq 262$ $\mathrm{mm}$ TL and females $\geq 214 \mathrm{~mm}$ TL were sexually mature. Both male and female gonads showed the presence of four maturation stages throughout the study period. 
TABLE 1

Sex ratio of males and females of Cichla monoculus during the study period.

\begin{tabular}{|l|c|c|c|c|c|}
\hline & \multicolumn{2}{|c|}{ Number } & \multicolumn{2}{c|}{ \% } & Males \\
\hline \multicolumn{1}{|c|}{ Month } & Females & Males & Females & 70 & $16.00^{*}$ \\
\hline August/97 & 3 & 7 & 30 & 80 & $36.00^{*}$ \\
\hline September97 & 1 & 4 & 20 & 45 & 1.00 \\
\hline October/97 & 5 & 4 & 55 & 50 & 0 \\
\hline November/97 & 4 & 4 & 50 & 60 & $4.00^{*}$ \\
\hline December/97 & 4 & 6 & 40 & 50 & 0 \\
\hline January/98 & 6 & 6 & 50 & 56 & 1.44 \\
\hline February/98 & 7 & 9 & 44 & 29 & $17.64^{*}$ \\
\hline March/98 & 12 & 5 & 71 & 46 & 0.64 \\
\hline April/98 & 7 & 6 & 54 & 47 & 0.36 \\
\hline May/98 & 9 & 8 & 53 & 47 & 0.36 \\
\hline June/98 & 8 & 7 & 53 & 29 & $17.64 *$ \\
\hline July/98 & 10 & 4 & 71 & 47.95 & 0.17 \\
\hline Total & 76 & 70 & 52.05 & & \\
\hline
\end{tabular}

* 5\% significance level.

Macroscopic observations of the gonad developmental stages showed that immature males had translucent, non-vascularised, thread-like testes, while the developing males had thread-like testes, which were milky white in appearance with evidence of vascularization. The testes of mature males appeared swollen, milky white and well vascularised and readily released milt under gentle pressure of the abdomen. Spent males had flaccid, empty testes with evidence of haemorrhaging.

Immature females had thread-like, translucent ovaries with oocytes invisible to the naked eye. In maturing females the ovaries were large, occupying one- to two-thirds of the body cavity, and were well vascularised with blood vessels. Mature females had swollen ovaries that occupied two-thirds of the body cavity and had large numbers of large oocytes as well as others of lesser sizes. The ovaries of spent females appeared flaccid. Only a few small oocytes were present and areas of haemorrhaging were apparent (Fig. 3).

Sections of the testes of immature males had spermatogonia present, while those from maturing fish showed the presence of both spermatogonia and spermatocytes. Maturation was readily apparent by the predominance of spermatozoids over spermatogonia and spermatocytes. In sections taken from spent males, large empty areas are apparent and only small numbers of spermatogonia, spermatocytes and spermatozoids were present (Fig. 4).

\section{Secondary sexual characteristics}

In young males it was possible to determine sex only after dissection. The onset of sexual maturity in 1+ males was marked by the appearance of a bright yellowish-orange post-occipital cephalic protuberance approximately two weeks prior to spawning. The mean height of the cephalic protuberance was $1 \mathrm{~cm}( \pm 0.2$ S.D.). Histological examination showed the presence of large quantities of oil droplets, which were absent in spent males (Fig. 5). The black spot present on the base of the caudal fin of both males and females had the same diameter as the eye $(16.5 \mathrm{~mm})$ and may have served to aid escape from predators. 

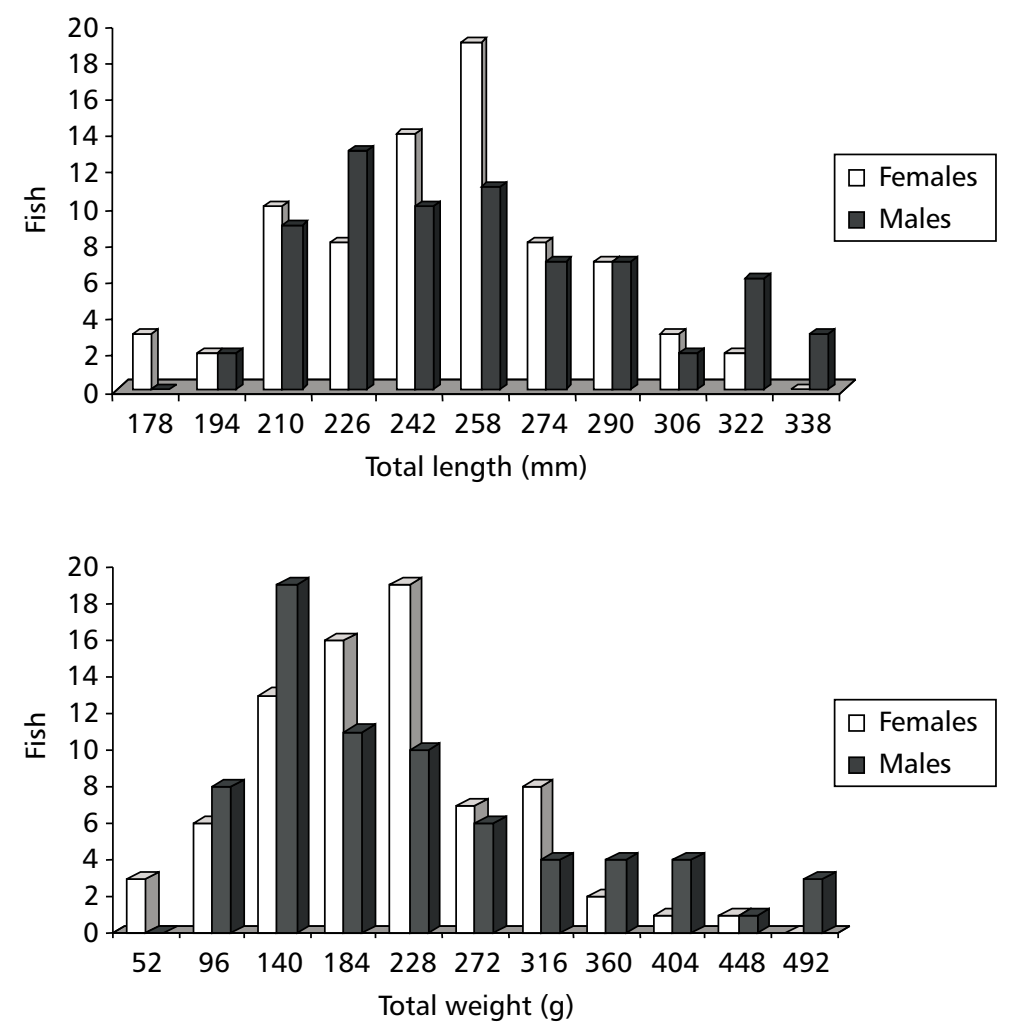

Fig. 2 - (a) Distribution frequency of length of males and females in the samples. (b) Distribution frequency of weight of males and females in the samples.

\section{Oocyte development}

Microscopic examination of ovaries showed that oocyte diameter varied from $100 \mu \mathrm{m}$ to 3000 $\mu \mathrm{m}$. Oocyte size frequency distributions show the simultaneous occurrence of oocytes of different size, indicating that each individual spawns more than once within a breeding cycle. In addition to cells in the initial stages of maturation, germ cells with well-defined cytoplasm and one or two spherical nucleoli predominated. Mature oocytes were also present, which were bigger and had rich lipid stores. Lacunae were apparent in the ovaries of spent females. The batch fecundity was estimated to be 3100 mature oocytes per female.

\section{CF, GSI and HSI}

The CF values of immature fish were relatively high (1.4) but decreased during gonadal maturation. In mature fish $\mathrm{CF}$ values decreased gradually during the breeding season and spent fish had low values (1.2). Trends were similar in both sexes. Sexually mature fish had high GSI values and in females these were as much as six times greater than in males. For example, the mean GSI of mature males in August 1997 was 0.27; the corresponding mean GSI of females was 1.86. Female GSI values showed two peaks, in October and April, whereas the males exhibited a similar but less pronounced pattern. The HSI was high for younger males (Fig. 6).

\section{DISCUSSION}

The present study documents the onset of sexual maturity and the seasonal changes in the reproductive activity of the introduced Cichla monoculus in Campo Grande Reservoir. The onset of sexual maturity was determined to be $>180 \mathrm{~mm}$ $\mathrm{TL}$ in males and $>200 \mathrm{~mm}$ TL in females. 

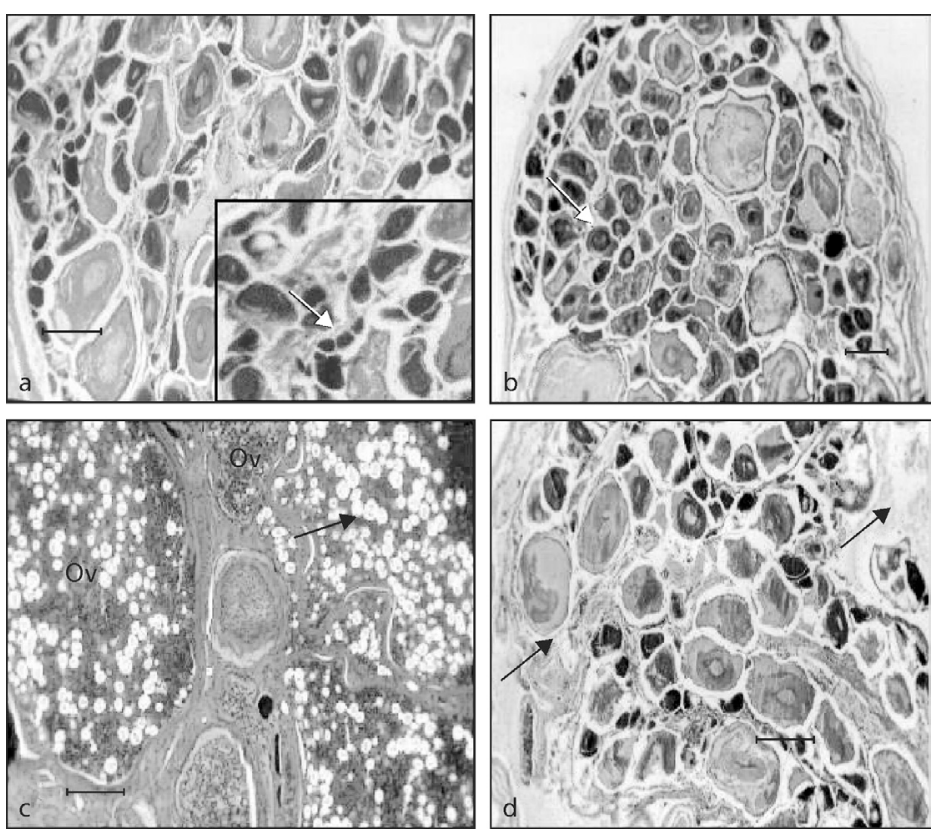

Fig. 3 - Gonad maturation stages of female $C$. monoculus (Scale bar, $50 \mu \mathrm{m}$ ).(a) Immature female, showing young germ cells (arrow). (b) Female in maturation, with well defined cytoplasm and nucleus and nucleolus (arrow). (c) Mature female showing presence of oocytes (Ov) with yolk granules (arrow). (d) Spent female showing vacant spaces in the ovary (arrow).
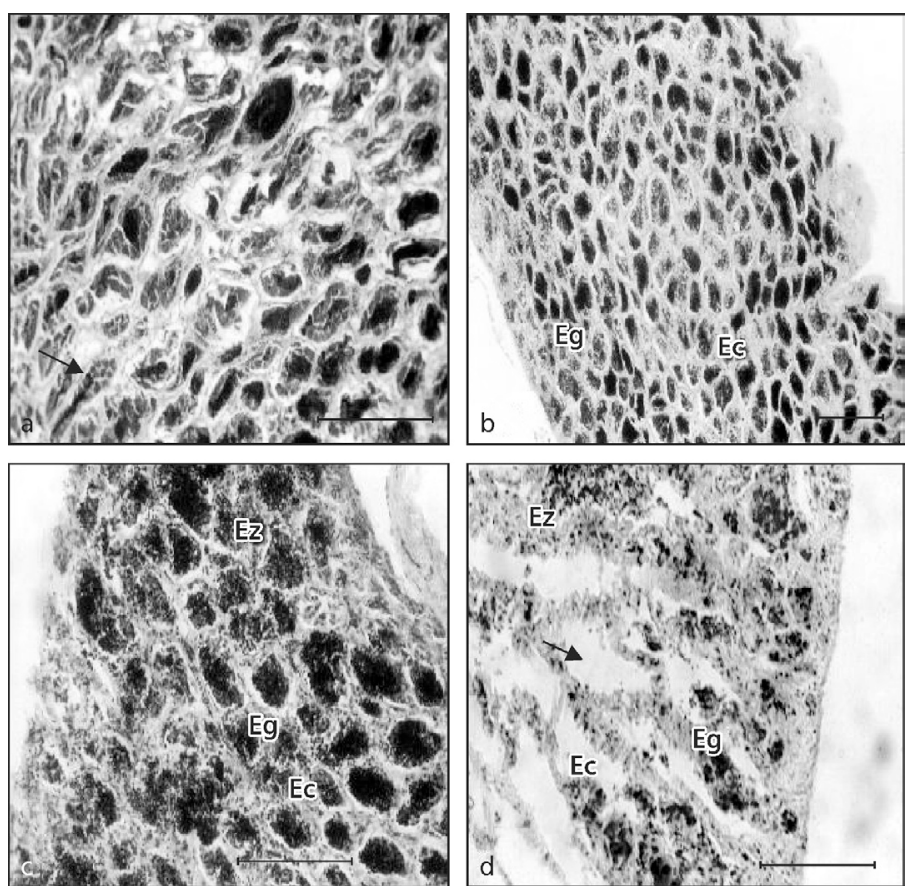

Fig. 4 - Gonad maturation stages of male $C$. monoculus (Scale bar, $50 \mu \mathrm{m}$ ). (a) Immature male, showing presence of spermatogonia (arrow). (b) Male in maturation, showing presence of spermatogonia (Eg) and spermatocytes (Ec). (e) Mature male showing the predominance of spermatozoids (arrow). (f) Spent male showing vacant spaces in the testes (arrow). 

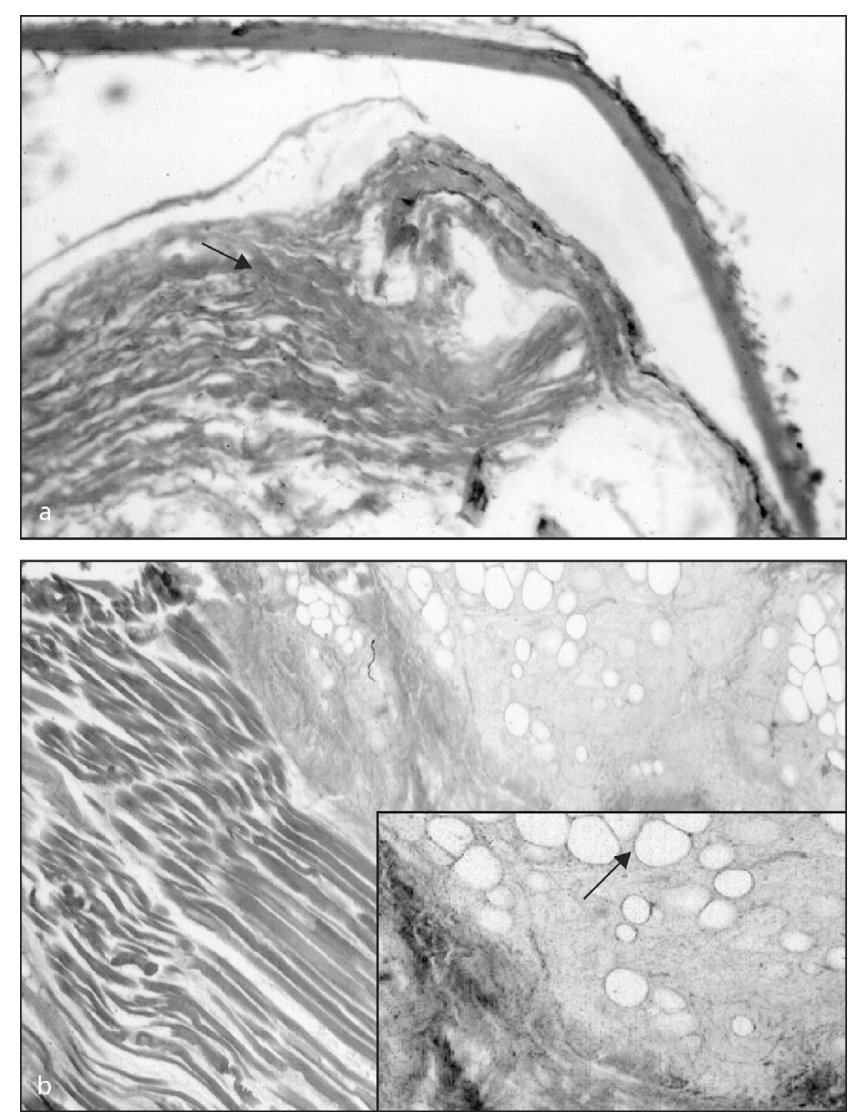

Fig. 5 - Histological aspects of the post occipital cephalic hump of males (Scale bar, $50 \mu \mathrm{m}$ ). (a) Immature male with predominant muscle tissue (arrow). (b) Mature male with lipid reserves.

Fifty percent of males $\geq 262 \mathrm{~mm}$ TL and females $\geq 214 \mathrm{~mm}$ TL were sexually mature. In an earlier study conducted in a different location in the neighbouring State of João Pessoa, it was found that males of $280 \mathrm{~mm}$ TL and females of $270 \mathrm{~mm}$ TL were sexually mature (Fontenele, 1950).

The GSI values indicate that there is an extended reproductive period with spawning occurring throughout the year. Macro and microscopic examinations of the ovaries indicate that $C$. monoculus is a multiple spawner. Females spawn three to four times during the annual reproductive cycle. Mature ovules are liberated in batches of 50 to 100, and spawning is completed in about 2 to 3 hours (Fontenele, 1950). Eggs are released on submerged tree trunks or on rocky substratum and is followed by a period of parental care (Chellappa et al., 1999).

In both sexes, $\mathrm{CF}$ had an inverse relationship with increasing gonadal maturation and spent fish were observed to be in poor condition. The present study showed lipid stores in the post-occipital cephalic protuberance of mature males, which were depleted in spent males. The lipid stores were probably mobilised during breeding and during parental care. Males are known to spawn within three weeks of the appearance of the cephalic hump (Fontenele, 1950; Machado, 1989). Both the semiarid tropical aquatic ecosystems and the Amazon basin receive consistently high insolation and constant periods of daylight and the waters have relatively similar turbidity values. In its native Amazonian basin, C. monoculus is known to inhabit both river channels and forest streams (Val \& Honczaryk, 1995). The adaptability of tucunare for growth, development and reproduction in a reservoir environment can be traced to their original habitat. Seasonal water fluctuations in the Amazon basin are commonly in the order of $4 \mathrm{~m}$ with concomitant changes in conductivity of 50 to $300 \mu \mathrm{Scm}^{-1}$. 

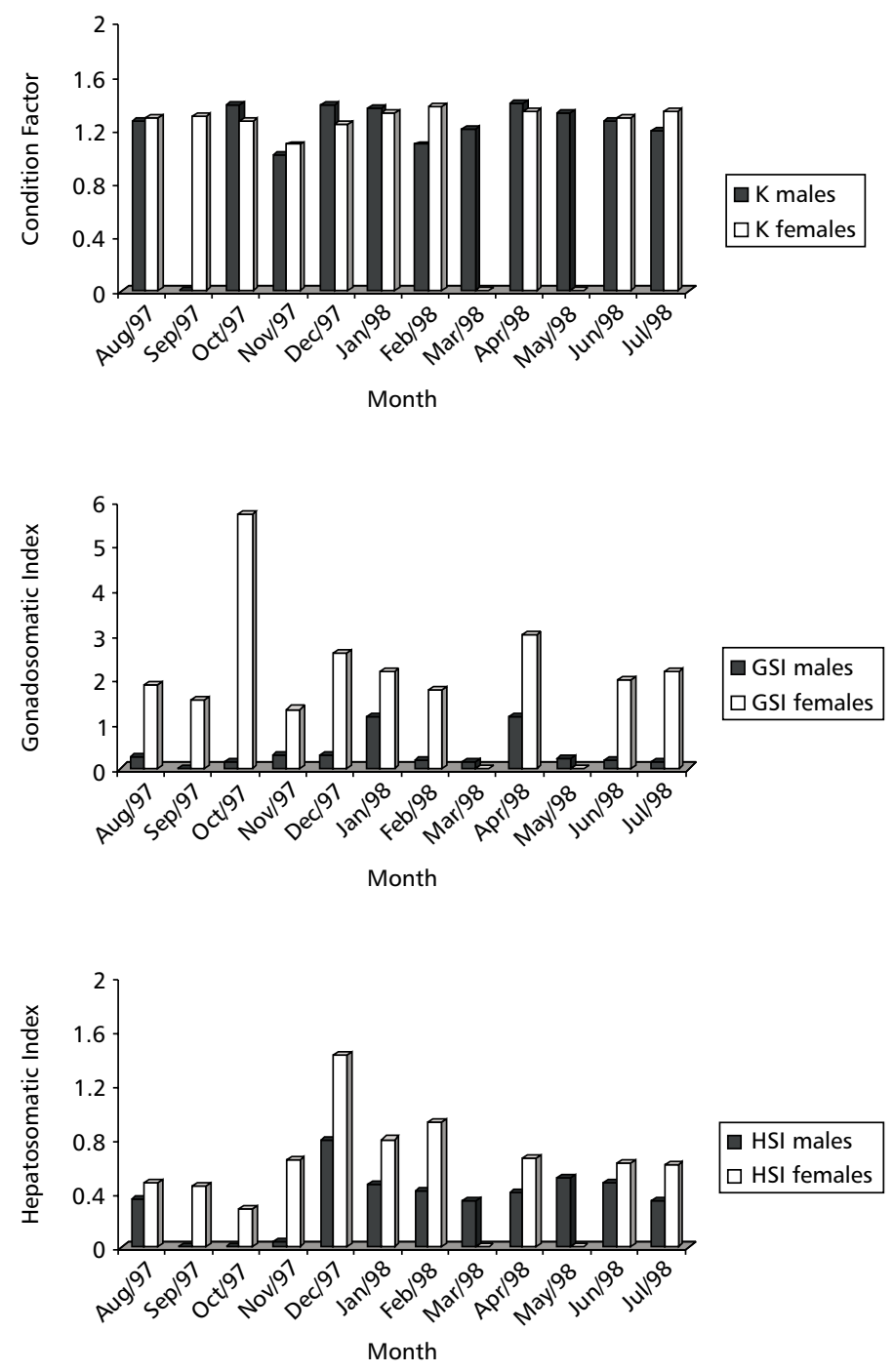

Fig. 6 - Mean monthly values of the Gonadosomatic Index (GSI) and Hepatosomatic Index (HSI) and Condition Factor (K) of males and females of Cichla monoculus.

Although there are some differences, both the Rio Solimões, for example, and associated forest streams are characterised by low nutrient levels (conductivity $57 \pm 8 \mu \mathrm{Scm}^{-1}$ and $10 \pm 3$ $\mu \mathrm{Scm}^{-1}$, respectively; sodium $2.3 \pm 0.8 \mathrm{mgL}^{-1}$ and $\left.2.3 \pm 0.8 \mathrm{mgL}^{-1}\right)$ and acidic $\mathrm{pH}$ values $(6.9 \pm 0.4$; $4.5 \pm 2$ ) (Val \& Almeida-Val, 1995; Val et al., 1996). There are also marked seasonal changes. In contrast, the reservoirs in the semi-arid northeast, such as the Campo Grande Reservoir, have characteristically high electrical conductivity (dry season/wet season average $1178.9 \mu \mathrm{Scm}^{-1}$ ) values and high levels of $\mathrm{Na}^{+}$ions (dry season/wet season average $125.0 \mathrm{mgL}^{-1}$ ). Campo Grande Reservoir is also highly nutrient rich and alkaline in nature. Conductivity levels in these reservoirs also appear to fluctuate in response to rainfall. During the dry season the impounded waters in São Paulo do Potengi were found to have high nutrient (conductivity $1031 \mu \mathrm{Scm}^{-1} ; 15 \pm 3 \mu \mathrm{Scm}^{-1}$; sodium $125 \mathrm{mgL}^{-1} \pm 1.2 \mathrm{mgL}^{-1}$ ) and alkaline $\mathrm{pH}$ values $(8.3 \pm 0.2)$. During the rainy season conductivity increased $\left(1260 \mu \mathrm{Scm}^{-1} ; 10 \pm 3 \mu \mathrm{Scm}^{-1}\right)$, sodium levels fell $\left(105 \mathrm{mgL}^{-1} \pm 1.0 \mathrm{mgL}^{-1}\right)$ and $\mathrm{pH}$ values 
were more or less circumneutral (7.0 to 7.2). These values are very different from the tucunare's Amazonian home range.

Reproductive strategies result from selection pressures on a species to produce the maximum number of young to survive until maturity under prevailing environmental conditions, thereby maximising fitness (see Potts \& Wootton, 1984; Turner \& Huntingford, 1986; Chase, 1999). Natural selection would be expected to favour changes in allocation of a species' resources from reproductive to competitive activities only where this enhances the survival of future offspring. The result of this is that organisms subjected to different selection pressures will have characteristic life history patterns (Brafield \& Llewellyn, 1982). Cichla monoculus clearly shows phenotypic plasticity in allocation of resources to growth or reproduction according to the environmental conditions. Cichla monoculus increases reproductive effort with the onset of adverse conditions. By contrast, red tilapia hybrids (Oreochromis sp.) respond to decreasing water levels by spawning at a smaller size and producing more batches of eggs, resuming allocation of energy to growth only when conditions improve (Sena \& Chellappa, 1991; Câmara, 1996).

Most natural habitats offer intermediate conditions so that fish will tend either to the $r$ end of the spectrum or the $\mathrm{K}$ end, where $\mathrm{r}$ refers to the strategy involving many small and fecund organisms, and $\mathrm{K}$ refers to the strategy involving larger and fewer organisms (Brafield \& Llewellyn, 1982; Chase, 1999). Cichla monoculus presents a high reproductive output coupled with repeated breeding (Iteroparoty), which provides for immediate population increase and effective exploitation of environmental resources.

\section{REFERENCES}

ABREU, V. L. B. \& SILVA, J. W. B., 1987, Análise da produção pesqueira em cinco açudes públicos administrados pelo Departamento Nacional de Obras Contra as Secas (DNOCS), período de 1966 a 1985. Bol. Téc. do DNOCS, Fortaleza, Brasil, 45(1/2): 27-50.

ALMEIDA, R. G., SOARES, L. H. \& EUFRÁSIO, M. M., 1993, Lagoa do Piató: peixes e pesca. Natal: CCHLA, UFRN., $84 \mathrm{p}$.

BRAFIELD, A. E. \& LLEWELLYN, M. J., 1982, Animal energetics. Glasgow, Blackie, 168p.

CÂMARA, M. R., 1996, Táticas reprodutivas do híbrido vermelho de tilápia, Oreochromis niloticus $x$ Oreochromis mossambicus (Pisces: Cichlidae). Monografia de Especialização, UFRN, Natal, Brazil, 31p.
CÂMARA, M. R. \& CHELLAPPA, S., 1996, Regime alimentar e adaptações morfo-anatômicas do trato digestivo dos Ciclídeos (Pisces: Cichlidae). Boletim do DOL/CB/UFRN, Natal, Brasil, 9: 59-66.

CHASE, J. M., 1999, To grow or to reproduce? The role of life-history plasticity in food web dynamics. Am. Nat., 154: 571-586.

CHELlAPPA, S., YAMAMOTO, M. E. \& CACHO, M. S. R. F., 1999, Reproductive behaviour and ecology of two species of Cichlid fishes. In: A. L. Val \& V. M. F. Almeida-Val (eds.), Biology of tropical fishes. Manaus, pp. 113-126.

FONTENELE, O., 1950, Contribuição para o conhecimento da biologia dos tucunarés (Acnopterygii, Cichlidae) em cativeiro: Aparelho de reprodução, hábitos de desova e incubação. Rev. Brasil. Biol., 8(2): 185-188.

LE CREN, E. D., 1951, The length-weight relationship and seasonal cycle in gonad weight and condition in the perch (Perca fluviatilis). Journal of Animal Ecology. London, 20: 201-219.

MACHADO, C. E. M., 1989, Criação prática de peixes. 2aㅗ ed., Ed. Nobel S/A, São Paulo, 116p.

MICHALANY, J., 1990, Técnica histológica em anatomia patológica com instruções para o cirurgião, enfermeira e citotécnico. 2a ed., São Paulo, 247p.

POTTS, G. W. \& WOOTTON, R. J. (eds.), 1984, Fish reproduction: strategies and tactics. Academic Press, London, 410p.

SANTOS, E. P., 1978, Dinâmica de populações aplicada à pesca e piscicultura. HUCITEC, São Paulo, 129p.

SENA, R. F. \& CHELLAPPA, S., 1991, Aspecto reprodutivo de híbrido vermelho de tilápia, Oreochromis niloticus (L.) x Oreochromis mossambicus (Peters), Pisces: Cichlidae. Boletim do DOL/CB/UFRN, Natal, Brazil, 8: 145-158.

STIRLING, H. P., 1985, Chemical and biological methods of water analysis for aquaculturists. University of Stirling, Scotland, 119p.

TURNER, G. F. \& HUNTINGFORD, F. A., 1986, A problem for game theory analyses: assessment and intention in male mouth brooder contests. Animal Behaviour, 34: 961-970.

VAL, A. L. \& ALMEIDA-VAL, V. M. F., 1995, Fishes of the Amazon and their environment. Physiological and Biochemical aspects. Springer Verlag, Heidelberg, 224p.

VAL, A. L., ALMEIDA-VAL, V. M. F. \& RANDALL, D. J., 1996, Physiology and biochemistry of the fishes of the Amazon. In: A. L. Val, V. M. F. Almeida-Val \& D. J. Randall (eds.), Physiology and Biochemistry of the Fishes of Amazon, 420p. INPA, Manaus.

VAL, A. L. \& HONCZARYK, A., 1995, Criando peixes na Amazônia. INPA, Manaus, 149p.

VAZZOLER, A. E. A. M., 1996, Biologia da reprodução de peixes teleósteos: teoria e prática. Editora SBI/UEM/ CNPq, Brasília, 169p.

WOOTTON, R. J., EVANS, G. W. \& MILLS, L. A., 1978, Annual cycle in female three-spined sticklebacks (Gasterosteus aculeatus L.) from an upland and lowland population. Journal of Fish Biology, 12: 331-343. 